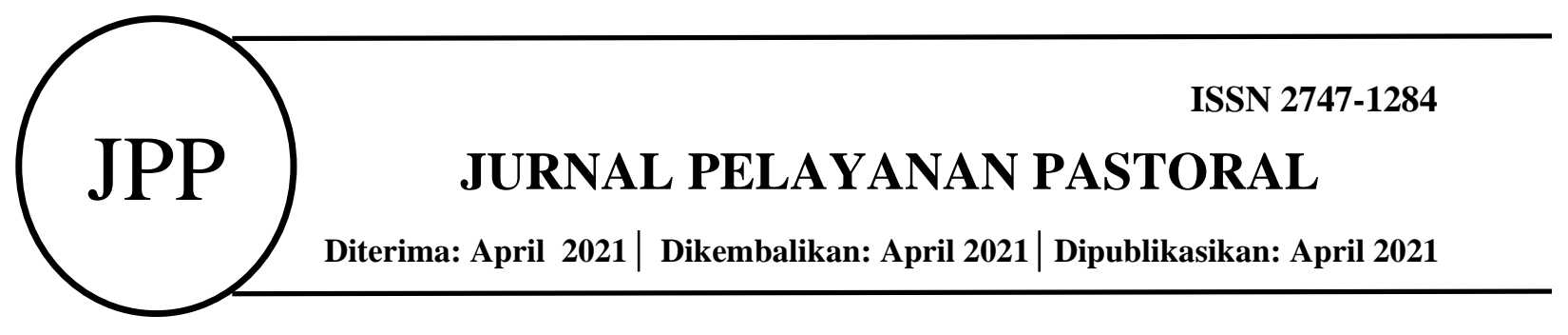

\title{
MENINGKATKAN KEAKTIFAN ANAK AUTIS \\ DALAM MENGIKUTI KEGIATAN MELALUI TERAPI BEHAVIORAL DI WISMA HALIMUN
}

\author{
Lorentius Goa ${ }^{1}$ \\ ${ }^{1}$ Dosen Prodi Pendidikan dan Pengajaran Agama Katolik STP-IPI Malang \\ e-mail: ${ }^{1}$ lorensgoa@gmail.com
}

\begin{abstract}
Abstrak
Istilah autisme berasal dari kata "auto" artinya "diri sendiri” sedangkan "isme” artinya "suatu aliran", kalau di gabung berarti suatu paham yang tertarik pada diri sendiri. Jadi, autisme adalah anak-anak yang tertarik dengan dunianya sendiri/menyendiri. Faktor penyebab autisme 8-11\% anak autis oleh genetik, selain itu juga disebabkan oleh genetic dan virus. Behaviorisme merupakan suatu pandangan ilmiah tentang perilaku manusia. Yang pada dasarnya adalah tingkah laku yang tertib dan eksperimen yang dikendalikan dengan cermat akan mengungkap hukum-hukum yang mengendalikan tingkah laku. Setiap individu memiliki kecenderungan-kecenderungan dengan positif dan negatif yang sama. Teori behavioristik adalah suatu teori yang menerapkan prinsip penguatan stimulus dan respons. Penguatan yang terbentuk melalui stimulus respons akan semakin kuat apabila diberi penguatan. Penelitian ini bertujuan untuk mendeskripsikan tentang tiga anak autis yang kurang aktif dalam mengikuti kegiatan terapi behavioral di Wisma Halimun. Penelitian ini menggunakan rancangan penelitian eksperimen kuantitatif. Berdasarkan hasil penelitian dengan metode yang dipakai pre-tes dan post-test Design untuk 5 sub variabel keaktifan anak maka diperoleh hasil sebagai berikut: AF dari pre-test mendapat nilai 56,6 dan pos test mendapat nilai 72,2 maka mengalami peningkatan 15,6. FG dari pre-test mendapat nilai 52, dan pos test mendapat nilai 65, maka mengalami peningkatan nilai sebanyak 13. Sedangkan KF dari pre-test mendapat nilai 53,2, dan post- test mendapat nilai 68,2 maka mengalami peningkatan 15. Jadi dilihat dari ketiga subyek tersebut yang mengalami peningkatan paling tertinggi AF 15,6 dan urutan kedua KF 15, dan FG 13.
\end{abstract}

Kata kunci: Autis, Terapi Behavioral.

\begin{abstract}
The term autism come from the word " auto" that means "yourself" whle" ism " means " a stream ", if you join it means that an understanding is interested in myself. So, autism is a child who is interested in his own world / aloof. Factor that cause autism $8-11 \%$ of children with are genetic, but it is also caused by genetics and viruses. Behaviorism is a scientific view of human behavior. It is basically orderly behavior and carefully controlled experiments will reveal the laws that control behavior. Every individual has the same positive and negative tendencies. Behavioristic theory is a theory that applies the principle of strengthening stimulus and response. This study aims to describe the three less active children in participating in the behaviour therapy activities at the Halimun Paulus underworld. This study used a quantitative experimental research design. Based on the results of the study with the methods used by pretest and posttest design for 5 subsidiaries of children's activeness, the following results are obtained : the first subject AF from the pretest got a score of 56,6 and the posttest got a value of 72,2, then an increase of 15,6. And the second subject FG from the pre-test got a value of 52, and the post test got a value 65, then it has increased in value by 13 . While the third subject of the KF from the pre-test received a value of 53,2, and the test post received a value of 68,2 , a 15 increase. So seen from the three subjects which experienced the highest increase in AF 15,6 and second order KF had an increase of 15, and the third had an increase of 13 .
\end{abstract}

Keywords: Autism, Behavioral Therapy 


\section{PENDAHULUAN}

Anak adalah anugerah yang luhur dari Tuhan yang diberikan melalui orangtua. Tuhan menghendaki agar setiap orangtua dapat menerima dan merawat serta mendidik anak-anak mereka dengan penuh tanggung jawab. Setiap orangtua pun menghendaki agar anak yang akan dilahirkan nanti menjadi anak yang baik dan sehat baik secara fisik maupun non fisik. Akan tetapi dalam kenyataannya banyak anak yang lahir dengan kondisi tidak normal baik secara fisik, mental maupun psikologi. Anak dengan kondisi dan keadaan yang berbeda dari anak pada umumnya tersebut disebut anak berkebutuhan khusus.

Anak Berkebutuhan Khusus (ABK) merupakan anak yang memiliki ciri yang berbeda dengan anak-anak pada umumnya, mereka mengalami hambatan dalam pertumbuhan dan perkembangannya. Mereka membutuhkan kegiatan dan layanan yang khusus agar dapat mencapai perkembangan yang optimal. Jumlah anak berkebutuhan khusus di Indonesia sudah mencapai 1,4 juta orang pada tahun 2014. Anak Berkebutuhan Khusus merupakan jenis gangguan yang dapat terjadi pada siapa saja khususnya pada balita sehingga peran orang tua sangat diperlukan dalam mengamati pertumbuhan dan perkembangan anaknya. Salah satunya yaitu dengan mengidentifikasi atau mengenali jenis dan karakteristik anak berkebutuhan khusus. Identifikasi anak berkebutuhan khusus diperlukan agar keberadaan mereka dapat diketahui sedini mungkin sehingga selanjutnya orang tua dapat melakukan tindakan apa yang harus dilakukan dalam menghadapi anak yang teridentifikasi, dan dapat melakukan pelayanan sesuai dengan kebutuhan khusus anak. Anak Berkebutuhan Khusus (ABK) dianggap berbeda dengan anak normal. Anak berkebutuhan khusus dianggap anak yang tidak berdaya sehingga perlu dibantu dan dikasihani. Pandangan ini tidak sepenuhnya benar. Setiap anak mempunyai kekurangan dan juga kelebihan. Oleh karena itu, anak berkebutuhan khusus memerlukan perhatian yang lebih, dengan demikian ia dapat mengembangkan potensi yang dimilikinya secara optimal (Handoyo, 2003).

Salah satu kasus atau masalah yang terjadi pada anak berkebutuhan khusus ialah autisme. Autisme berkaitan dengan sejumlah keadaan yang ditandai dengan hambatan sosial, perilaku yang berulang, kelainan bahasa dan komunikasi dan disertai dengan keunikan dan keanehan. Autisme merupakan kelainan yang berlangsung sepanjang hidup yang mempengaruhi cara individu tersebut berinteraksi dengan lingkungannya dan orang-orang di sekitarnya. Anak autisme biasanya memiliki gerakan atau tindakan aneh tertentu yang dilakukan berulang-ulang, seperti bertepuk tangan, memutar tangan dan lain-lain. Bila ia suka bergerak berputar-putar maka ia akan dalam waktu lama melakukan kegiatan itu. Fokus pandangnya tampak tidak normal, ia biasa melihat suatu benda dengan sudut mata. Anak ini akan mengalami kesulitan dalam hal permainan yang bervariasi. Misalnya saat ini suka bermain dengan kertas maka dalam waktu tertentu ia akan terus bermain dengan kertas tersebut dan tidak dapat pindah ke aktivitas yang lain. Anak dengan autis sebisa mungkin dibantu dengan memberikan perhatian penuh kepada mereka melalui latihanlatihan yang membantu mereka dalam bertumbuh dan berkembang.

Untuk itu anak dengan autis memerlukan sebuah terapi. Menurut Kamus Besar Bahasa Indonesia terapi merupakan usaha untuk memulihkan kesehatan orang yang sedang sakit, pengobatan penyakit, dan perawatan penyakit. Salah satu terapi yang dapat digunakan pada anak dengan autis ialah terapi behavioral. Terapi behavioral merupakan suatu terapi yang digunakan untuk penanganan perilaku anak dengan autis yang memiliki permasalahan dengan perilakuperilaku yang dilakukan anak dengan autis. Perilaku (behavioral) adalah apa pun yang dikatakan atau dilakukan seseorang. Sinonim yang digunakan untuk istilah perilaku adalah 'aktivitas, tindakan, aksi perbuatan, respon dan reaksi'. Istilah perilaku juga dapat merujuk pada aktvitas perilaku yang tidak kelihatan (covert behavioral), perilaku yang kelihatan atau terlihat (covert 
behavioral) (Gari, dkk 2015). Jadi, terapi behavioral merupakan suatu usaha untuk memulihkan, merawat, dan mengobati apa pun yang dikatakan atau dilakukan seseorang baik yang kelihatan maupun yang tidak kelihatan.

\section{METODE PENELITIAN}

Dalam penelitian ini, peneliti menggunakan desain penelitian Eksperimen. Metode desain yang digunakan oleh peneliti adalah Pre-Eksperimental Desain (nondesign) atau eksperimen OneGroup Pretest-Posttest Design. Karena desain ini terdapat pre-test sebelum memberi perlakuan. Dengan demikian dapat diketahui lebih akurat, karena dapat dibandingkan dengan keadaan sebelum diberi perlakuan. Dalam desain ini kelompok yang digunakan oleh peneliti tidak dapat dipilih secara random. Sebelum diberi treatmen kelompok diberi pre-test. Setelah hasil pre-test diperoleh kelompok tersebut baru diberi treatmen (Supardi, 2005).

\section{HASIL DAN PEMBAHASAN}

\section{Autisme}

Autisme berasal dari kata autos yang artinya segala sesuatu yang mengarah pada diri sendiri. Istilah autis diperkenalkan pertama kali pada tahun 1943 oleh Dr. Kanner seorang psikiater anak dari Universitas Johns Hopkins. Kanner menyatakan bahwa pada sekelompok anak yang ditelitinya terlihat adanya suatu gangguan mendasar di mana sejak awal kehidupan tidak mampu melakukan interaksi sosial terhadap orang lain atau situasi tertentu seperti halnya anak normal. Selain itu ditemukan adanya kegagalan dalam membangun kemampuan berkomunikasi atau terjadinya keterbatasan dalam bahasa. Autisme adalah gangguan perkembangan pada anak, oleh karena itu diagnosis ditegakkan dari gejala-gejala yang tampak menunjukkan adanya penyimpangan dari perkembangan yang normal sesuai umurnya. Organisasi kesehatan dunia (WHO) telah merumuskan sesuatu kriteria yang harus di penuhi untuk dapat menegakkan diagnosis autisme. Rumusan ini di pakai di seluruh dunia dan di kenal dengan sebutan ICD-10 (International Clasification Of Diseases) 1993. Rumusan diagnostik lain yang juga di pakai di seluruh dunia untuk menjadi panduan diagnosis adalah yang di sebut DSM-1V (Diagnostic And Statistical Manual) 1994, yang di buat oleh grup psikiatri dari amerika. Isi ICD-10 maupun DSM1V sebenarnya sama (Nugraheni, 2012).

Autisme Spectrum Disorder (ASD) merupakan sebuah gangguan perkembangan pervasif. Gangguan Autisme Spectrum Disorder ASD) merupakan suatu kondisi abnormalitas nyata, yaitu gangguan perkembangan pada interaksi sosial dan komunikasi serta terbatasnya aktivitas dan minat. Dari beberapa pendapat di atas dapat disimpulkan bahwa gejala-gejala gangguan autis yakni sebuah gangguan perkembangan pada kemampuan anak autis yang mengalami hambatan dalam interaksi sosial, komunikasi dan perilaku yang merupakan kondisi nyata yang perlu dikembangkan dari keterbatasan menjadi kemampuan yang mampu berintraksi, komunikasi dan perilaku dengan baik.

Gejala autis sesungguhnya telah dapat di kenal sejak masa bayi. Gejala autis umumnya terlihat dalam 3 bulan pertama (biasa di kenal dengan istilah early infantile autisme yaitu gangguan autis yang terjadi sejak anak lahir). Perbedaan yang jelas ditujukan oleh anak autis dari anak normal lainnya yaitu ketika ia berusia 4 bulan di mana pada anak normal telah mampu mengadakan kontak mata dengan orang lain, tetapi hal ini tidak muncul pada anak yang mengalami gangguan autis (Hildayani dkk, 2016). Gejala autis mulai nampak sebelum anak berusia 3 tahun, bahkan pada autistic infantile gejalanya sudah ada sejak lahir. Berdasarkan penelitian diperkirakan penyebab munculnya gejala autis adalah bahan metabolisme sebagai hasil proses (asam organik) 
merupakan bahan yang dapat mengganggu fungsi otak dan keadaan tersebut biasanya didahului dengan gangguan pencernaan. Penyebab bahan metabolit dari hasil proses metabolisme inilah yang mengakibatkan anak autis mengalami gangguan perilaku.

\section{Metode Pembelajaran Bagi Anak Autis}

Biasanya dalam metode pembelajaran untuk anak autis disesuaikan dengan usia dari anak tersebut, kemampuan yang dimiliki, serta hambatan yang dimiliki anak saat mereka belajar, serta gaya belajar atau lerning style-nya pada masing-masing anak. Metode yang biasanya diberikan adalah bersifat kombinasi dari beberapa metode. Meskipun tidak terlalu banyak ada juga anak yang menderita autis yang memiliki respon yang sangat baik terhadap stimulus visual sehingga metode belajar yang menggunakan stimulus visual sangat diutamakan bagi mereka. Pembelajaran yang menggunakan alat bantu bisa dijadikan sebagai pilihan yakni: anak didampingi oleh seorang terapis yang berfungsi sebagai guru pembimbing khusus dalam proses pendidikannya.

Metode pembelajaran yang digunakan dalam melatih anak autis menggunakan media pembelajaran yakni kegiatan terapi behavioral. Dalam melatih anak menggunakan Program Terpadu Bhakti Luhur (PTBL). Yakni dalam kegiatan terapi behavioral, pelatih menyediakan hadiah baik berupa materi maupun lisan untuk mendorong anak mengikuti terapi behavioral dengan baik. Program inilah yang menjadi metode bagi pengasuh dalam melatih anak autis melalui terapi behavioral. Selain itu ketika pengasuh menjelaskan kegiatan terapi behavioral kepada anak akan disertai dengan penjelasan dengan menggunakan bahasa sederhana agar anak dengan mudah paham.

Proses pembelajaran anak autis harus membutuhkan seorang pendamping atau pembimbing yang memiliki pengetahuan cukup tentang autis. Pendamping harus memberi perhatian dan bekerja secara optimal karena anak autis memiliki banyak kekurangan terutama dalam perilaku, mental dan komunikasi. Pengasuh juga mampu menciptakan suasana yang gembira, suasana siap belajar dengan demikian anak akan termotivasi untuk belajar. Biasanya pendampingan secara penuh atau selalu diawasi yakni anak dengan tingkat perilaku yang masih sangat rendah sehingga perlu pendampingan oleh pengasuh tetapi pengasuh berusaha melatih meningkat kemampuan anak agar mandiri. Seringkali pengasuh mendampingi anak belajar dengan melalui kegiatan terapi dengan penjelasan agar anak dengan mudah memahami. Tetapi bagi anak autis yang mengalami peningkatan maka pendampingan akan dikurangi dan membiarkan anak belajar mandiri dan selalu dalam pengawasan pengasuh.

\section{Suasana Belajar Yang Tepat Untuk Anak Autis}

Sebenarnya semua tergantung pada setiap anak, tergantung pada kemampuan anak dan gaya belajar setiap anak penderita autis. Pada umumnya anak autis akan mendapat hasil yang lebih baik dalam belajar apabila digabungkan dengan anak-anak normal maupun yang memiliki keterbatasan namun anak autis yang lebih senang apabila dia ditempatkan pada suatu tempat dengan kondisi yang tenang. Tergantung setiap anak, yang paling penting adalah bagaimana pembimbing lebih mengenal setiap karakter anak dengan pengenalan lebih memudahkan dalam memberi materi pelajaran bagi anak autis. Anak autis akan merasa senang jika ruangan yang nyaman dan banyak benda-benda yang menarik di tambah dengan pendamping yang dapat memahami dan mengerti karakter anak autis.

Belajar dapat terlaksana jika ruangan yang tenang, benda-benda yang menarik dengan demikian pembelajaran dapat menarik perhatian anak, oleh sebab itu pengasuh menggunakan media pembelajaran yakni kegiatan terapi behavioral. Melatih anak autis dengan melalui kegiatan 
yang indah dan menarik perhatian anak, memfokuskan atau mengalihkan perhatian anak untuk belajar. Pengasuh harus kreatif melihat situasi anak autis artinya jika anak mulai merasa bosan pengasuh harus kreatif mencari cara agar suasana tidak membosankan bagi anak autis. Pengasuh harus mengenal karakter setiap anak karena tingkat kemampuan anak autis berbeda-beda oleh sebab itu pengasuh di tuntut mengenal tingkat kemampuan dan kelemahan yang dimiliki anak.

Terapi perilaku adalah terapi yang bertujuan memperbaiki dan membentuk pola perilaku anak autis agar terbentuk pola perilaku yang baik. Pola perilaku anak autis yang berlebihan dikurangi dan yang berkekurangan akan di bentuk. Tujuan penanganan ini terutama adalah untuk meningkatkan pemahaman dan kepatuhan anak terhadap aturan. Melalui gaya pengajaran yang terstruktur anak autis kemudian memahami behavioral (perilaku) apa yang diharapkan dilakukan olehnya sesudah instruksi tersebut diberikan dan perilaku tersebut diharapkan cenderung terjadi lagi bila anak memperoleh consequence (konsekuensi perilaku atau kadang berupa imbalan) yang menyenangkan. Tujuan dari pemahaman ini untuk meningkatkan pemahaman dan kepatuhan anak terhadap aturan. Demikian pun dengan bermain, dengan bermain dapat melatih fisik, intelektual, emosi dan juga dengan bermain dapat dilihat kemampuan yang dimiliki anak. Setiap kegiatan yang dilakukan untuk kesenangan yang ditimbulkan tanpa mempertimbangkan hasil akhir.

Fakta yang terjadi dalam melatih anak autis seringkali tidak fokus dan tidak tenang bila memberikan pelatihan oleh pengasuh di sebabkan anak lebih suka dengan dunianya sendiri tidak mau diganggu. Dengan demikian pengasuh menerapkan terapi perilaku bagi anak autis demi meningkatkan kemampuan pada anak autis misalnya pengasuh melatih anak untuk mengikuti kegiatan lewat terapi behavioral dengan baik dan dengan memberi hadiah dan pujian.

\section{Terapi Behavioral}

Behaviorisme merupakan suatu pandangan ilmiah tentang perilaku manusia. Yang pada dasarnya adalah tingkah laku yang tertib dan eksperimen yang dikendalikan dengan cermat akan mengungkap hukum-hukum yang mengendalikan tingkah laku. Setiap individu memiliki kecenderungan-kecenderungan positif dan negatif yang sama. Teori behavioristik adalah suatu teori yang menerapkan prinsip penguatan stimulus dan respons. Penguatan yang terbentuk melalui ikatan stimulus respons akan semakin kuat apabila diberi penguatan. Penguatan positif sebagai stimulus dapat meningkatkan terjadinya pengulangan perilaku, sedangkan penguatan negatif dapat mengakibatkan perilaku berkurang atau menghilang (Buku Pusat Pengembangan Rehabilitasi; 2011). Bahwa modifikasi periaku adalah usaha mengubah perilaku dan emosi manusia dengan cara yang menguntungkan berdasarkan hukum-hukum teori modern proses belajar.

Salah satu metode intervensi dini yang banyak diterapkan di Indonesia adalah modifikasi perilaku atau lebih dikenal sebagai metode Applied Behavioral Analysis (ABA). Kelebihan metode ini dibandingkan dengan metode lain adalah sifatnya yang sangat terstruktur, kurikulumnya jelas, dan keberhasilannya bisa dinilai secara objektif. Penatalaksanaannya dilakukan 4-8 jam hari. Melalui metode ini, anak dilatih melakukan berbagai macam keterampilan yang berguna bagi hidup bermasyarakat, misalnya berkomunikasi, berinteraksi, berbicara, berbahasa. Namun, yang pertama-tama perlu diterapkan adalah latihan kepatuhan. Hal ini sangat penting, agar mereka dapat mengubah perilaku seenaknya sendiri menjadi perilaku yang lazim diterima masyarakat. Bila latihan ini tidak dijalankan secara konsisten, maka perilaku itu akan sulit diubah. Bila sudah dewasa, anak seperti itu acap kali akan dikatakan kurang mengenal sopan santun (Atmaja, 2020). 


\section{Tahap-tahap Terapi Behavioral}

Tahap-tahap terapi behavioral terdiri atas 4 tahap yaitu: 1) Pengukuran (assesment). Halhal yang digali dalam assesment meliputi analisis tingkah laku bermasalah yang dialam konseli saat ini, yaitu analisis situasi yang di dalamnya terjadi masalah konseli; analisis self-control; analisis hubungan sosial; dan analisis lingkungan fisik-sosial budaya (Martin, dkk, 2015). 2) Menentukan Tujuan. Tujuan yang ditetapkan digunakan sebagai tolak ukur untuk melihat keberhasilan proses terapi. Proses terapi akan dihentikan jika telah mencapai tujuan. Tujuan terapi harus jelas konkret, dipahami, dan disepakati oleh klien dan konselor. Konselor dan klien mendiskusikan perilaku yang terikat dengan tujuan keadaan yang diperlukan untuk perubahan sifat tujuan dan rencana tindakan untuk bekerja ke arah tujuan tersebut. 3) Mengimplementasikan Teknik. Setelah merumuskan tujuan yang ingin di capai, konselor dan konseling menentukan strategi belajar yang terbaik untuk membantu konseling mencapai perubahan tingkah laku yang diinginkan. Konselor dan konseling mengimplementasikan teknik-teknik konseling sesuai dengan masalah yang dialami oleh konseling. 4) Mengakhiri Terapi Behavioral. Proses terapi akan berakhir tujuan yang ditetapkan di awal terapi telah tercapai. Meskipun demikian, terapi tetap memiliki tugas yaitu terus melaksanakan perilaku baru yang diperolehnya selama proses konseling di dalam kehidupannya sehari-hari.

\section{Tujuan Terapi Behavioral.}

Terapi behavioral menfokuskan pada persoalan-persoalan perilaku spesifik atau perilaku menyimpang yang bertujuan untuk menciptakan kondisi-kondisi baru bagi proses belajar dengan dasar bahwa segenap tingkah laku itu dipelajari, termasuk tingkah laku yang maladaptif. Terapi behavioral dapat membangun dan membentuk suatu perilaku yang baik bagi penerima terapi. Terapi behavioral memiliki kelebihan maupun kelemahan. Kelebihan Terapi Behavioral adalah pembuatan tujuan terapi antara terapi dan klien diawal dijadikan acuan keberhasilan proses terapi, memiliki berbagai macam teknik konseling maupun terapi yang teruji dan selalu diperbaharui, waktu terapi relatif singkat, dan kolaborasi yang baik antara terapi dan klien dalam penetapan tujuan dan pemilihan teknik. Kelemahan Terapi Behavioral adalah dapat mengubah perilaku tetapi tidak mengubah perasaan, mengabaikan faktor relasional penting dalam terapi, tidak memberikan wawasan, mengobati gejala dan bukan penyebab, dan melibatkan kontrol dan manipulasi oleh konselor.

\section{Kegiatan di Wisma Halimun.}

Wisma Halimun adalah salah satu wisma yang ada di bawah naungan Yayasan Bhakti Luhur. Di dalam wisma tersebut terdapat juga anak dengan autis. Kasus yang terjadi pada anak autis di Wisma Halimun adalah anak autis yang tidak mau mengikuti kegiatan-kegiatan yang dilaksanakan dalam wisma sebab anak lebih suka menyendiri, dan sulit jika diajak mengikuti kegiatan. Melihat masalah di atas peneliti bertujuan membantu anak tersebut agar aktif dalam mengikuti kegiatan di wisma melalui terapi behavioral.

Terapi ini dapat menangani semua jenis perilaku, mulai dari perilaku yang dipelajari sampai perilaku yang di sebabkan oleh lingkungan. Tujuan dari terapi ini adalah membantu dan mempersiapkan anak untuk menghadapi berbagai tantangan tanpa harus beralih kekebiasaan buruk sebagai mekanisme pertahanan. Beberapa penyakit yang dapat diobati dengan terapi behavioral misalnya depresi dan fobia sosial. Terapi behavioral juga bermanfaat bagi pasien yang menderita Autisme. Maka terapi behavioral ini, dapat digunakan untuk membantu anak dengan autisme agar aktif dalam mengikuti kegiatan. 
Berdasarkan hasil pre-test dan post-test yang diperoleh, peneliti dapat menyimpulkan bahwa dengan adanya kegiatan terapi behavioral ini dapat mempengaruhi anak autis yang kurang aktif dalam kegiatan. Hal ini dapat dilihat hasil pre-test dari kegiatan pada sub variabel mendemonstrasikan mencapai 75 , hasil pos test yaitu 68,2. Jadi jumlah dari rata-rata pre-test dari kegiatan ketuhanan, kegiatan kesenian, kegiatan keterampilan, kegiatan olahraga, kegiatan berkebun adalah 52,6 Jumlah peningkatan dari hasil pre-test dan post-test adalah 14,5.

\section{KESIMPULAN}

Berdasarkan penjelasan dan pembahasan dari bab-bab sebelumnya, pada bagian yang terakhir ini penulis akan menyimpulkan mengenai: Upaya Meningkatkan Keaktifan Anak Autis Dalam Mengikuti Kegiatan Lewat/Melalui Terapi Behavioral Di Wisma Halimun Paulus Bawah khususnya ditempuh dengan menerapkan teknik-teknik dan langkah-langkah terapi behavioral. Analdi, mengatakan bahwa teori behavioristik adalah suatu teori yang menerapkan prinsip penguatan stimulus dan respon. Behaviorisme merupakan suatu pandangan ilmiah tentang perilaku manusia. Yang pada dasarnya adalah tingkah laku yang tertib dan eksperimen yang dikendalikan dengan cermat akan mengungkap hukum-hukum yang mengendalikan tingkah laku. Setiap individu memiliki kecenderungan-kecenderungan dengan positif dan negatif yang sama.

Teroi behavioristik adalah suatu teori yang menerapkan prinsip penguatan stimulus dan respon. Penguatan yang terbentuk melalui stimulus respons akan semakin kuat apabila diberi penguatan. Penguatan positif sebagai stimulus dapat meningkatkan terjadinya pengulangan perilaku, sedangkan penguatan negatif dapat mengakibatkan perilaku berkurang atau menghilang. Berdasarkan hasil penelitian dengan metode yang dipakai pre-test dan post-test Design untuk 5 sub variabel keaktifan anak maka diperoleh hasil sebagai berikut: subyek pertama AF dari pretest mendapat nilai 56,6 point dan post-test mendapat nilai 72,2 point maka mengalami peningkatan 15,6 point. Dan subyek kedua FG dari pre-test mendapat nilai 52 point, dan pos test mendapat nilai 65 point, maka mengalami peningkatan nilai sebanyak 13 point. Sedangkan subyek ketiga KF dari pretest mendapat nilai 53,2 point, dan pos test mendapat nilai 68,2 point maka mengalami peningkatan 15 point. Jadi dilihat dari ketiga subyek tersebut yang mengalami peningkatan paling tertinggi AF 15,6 point dan urutan kedua KF mengalami peningkatan 15 point, dan yang ketiga mengalami peningkatan 13 point.

\section{DAFTAR PUSTAKA}

Adikanto, Suharsimi. (2005). Menejemen Penelitian. Jakarta: PT Rineka Cipta, Cetakan ke: 7.

A. S, Nugraheni. (2012). Menguak Belantara Autisme. Yogyakarta: Fakultas Psikolgi Universitas Gadjah Mada.

Jati, Atmaja Rinakri. (2017). Diakses pada Minggu,10 Januari 2020. Pukul 23.00 WIB

Buku Pusat Pengembangan Rehabilitasi Bersumberdaya Masyarakat. (2011). Malang: Bhakti

Luhur Malang.

Gari, Martin dan Pear, Joseph. (2015). Modifikasi Perilaku Makna dan Penerapannya.

Yogyakarata: Pustaka Pelajar.

Handayani, E. (2003). Autism pada Twins: Studi Kasus Pada Satu Pasang Anak Kembar Yang

Mengalami Autistic Disorder, Tugas Akhir. Jakarta: Universitas Indonesia.

Handoyo. (2003). Autisme: Petunjuk Praktis dan Pedoman Materi untuk Mengajar Anak Normal,

Autis, dan Perilaku Lain, Cetakan kedua. Jakarta: PT Bhuna ilmu Populer.

Hildayani, Dkk Rini, 2016. Penanganan Anak Berkelainan, Tangerang Selatan: Universitas: 
Terbuka.

http://divaangreyani.Blogspot.com/2013/04/terapi-behavioral-behavior-therapy.html Janet Key, 2013. Pendidikan Anak Usia Dini, (Kanisius: Jln. Cendrawasihno. 4 AB. Supardi, 2005. Metodologi Penelitian Ekonomi dan Bisnis, (Yogyakarta: UII Press. Sugiyono, Metode Penelitian Kuantitatif Kualitatif dan $R \& D$. 